\title{
DEVELOPING STUDENTS' CRITICAL THINKING THROUGH AN INTEGRATED EXTENSIVE READING PROGRAM
}

\author{
Nida Husna \\ (nida.husna@uinjkt.ac.id) \\ Syarif Hidayatullah State Islamic University \\ Jl. Ir. H. Juanda No. 95, Ciputat 15412, Indonesia
}

\begin{abstract}
This study was conducted to help English teacher candidates maximize their efforts to develop critical thinking skills through an Extensive Reading (ER) program. There were forty research participants, from 18 to 21 years age range, in their fourth semester of undergraduate study in English Education Department. The main instrument to collect the data was a test in Critical Thinking, which was given before and after the program. The students were also asked to share their perception about the program after it ended by writing a reflection. During the ER program, the students practiced exercising their critical thinking skills in the post-ER activities which integrated all the four language skills. They needed to demonstrate their critical thinking as a required part of the assessment to provide evidence for their ER activities. Findings from the Critical Thinking test indicate improvement in the students' critical thinking skills after the program. They also had positive perceptions of the activities and assessment in the program, which they thought to have positive influence on their critical thinking. All these imply the potential of integrating the development of critical thinking skills in an ER program.
\end{abstract}

Keywords: extensive reading, critical thinking, assessment, L2 students

DOI: http://dx.doi.org/10.15639/teflinjournal.v30i2/212-230

For decades, the focus of teaching English in Indonesia has been to prepare students to use the language as a means of communication so they can compete globally. However, the need to support the government in preparing more English-competent Indonesian employees spurred many educators to include 
some other elements that can help the students to also develop their creativity and critical thinking skills in the teaching-learning process.

The development of critical thinking skills as part of ESL/EFL reading classroom activities has become the focus of several studies. Some of these studies were to develop college students' critical thinking skills that focused on skills that were widely applicable (Halpern, 1999); to assess critical thinking instructions and the teachers' commitment (Paul, Elder, \& Bartell, 2007); to see how critical thinking is related to extensive reading (Eftekhary \& Kalayeh, 2014) and to examine its effect on other elements of study (Reed, 1998). Those who have good critical thinking skills tend to be good at organizing complex matters, diligent in searching for related information, and persistent in trying to find out the most appropriate solutions when they are facing problems (Camarata, 2017; Facione, Facione, \& Giancarlo, 1997; Eftekhary \& Kalayeh, 2014).

Some studies have examined the influence of extensive reading on critical thinking or how the amount of reading can influence critical thinking development. For example, Jimenez, Haydee, Rosales, and Soraya (2010) conducted a study in El Salvador which aimed at finding out whether reading for pleasure can help their ESL students develop their ability in critical thinking by exposing students to the real world. Their data showed that the students became familiar with the scientific style of reading which helped them write their arguments logically. The study also concluded that reading widely could help the students avoid poor decision-making in their life because they were able to use that information to build a logical framework to deal with real world difficulties.

Eftekhary \& Kalayeh (2014) looked at how extensive reading can improve ESL/EFL students' critical thinking ability at the Rasht Branch of Azad University. They argue that including the development of critical thinking in reading activities was a significant way to help students solve problems. It was found that the students with good critical thinking skills could comprehend the reading materials better, and that good comprehension in reading could improve the students' overall critical thinking.

In another study, Tabačková (2015) focuses on students' point of view of the text, acting as critics of their reading, and focusing on critical thinking by dissecting a poem after they understood the text and its structure. By doing so, students could see that a phrase can have different meanings in different contexts and when it stands alone. They learn to derive meaning from each 
stanza as a stand-alone sentence and relate them to the real world. Tabačková (2015) also stated that literature was a means of developing critical thinking practice as well as building knowledge and developing moral attitudes.

Another study on applying critical thinking skills in reading was conducted in an Intensive English Program (IEP) in Minnesota with $61 \%$ of the students were Saudi students (Wong, 2016). It was found that those students were likely to use oral reading as a main strategy because it was part of their culture to memorize, rather than to recite. At first, the reading was challenging because the students had to read in a code different from their own; however, follow-up collaborative activities helped those students. The first step was analyzing and inferring ideas in the text and then participating in critical thinking and problem-solving activities which encouraged them to create solutions to real-world problems.

Based on the above studies, it can be seen that some practical and straightforward reading activities in encouraging the critical thinking skills can be applied in the classrooms where English is not the mother tongue, such as in Indonesia. Generally, critical thinking skills can be summarized as the ability to find any possibilities when solving a problem, considering different perspectives and being able to see the others' argument as part of an alternative contribution, or conclusions, on a specific topic (Jimenez et al., 2010).

Critical thinking is not a specific subject that should be taught separately with its own syllabus (Pikkert \& Foster, 1996). Some core critical thinking skills include interpretation, analysis, evaluation, inference, explanation, and self-regulation, and can be conducted in reading classes with activities to empower the students' critical thinking ability (Facione, 1990). This study posits that through the extensive practice of reading critically, students can learn how to stimulate their thoughts to see various perspectives within the discourse. As we saw in the Tabačková's (2015) study with literature, it seems that what happened outside the classroom can be brought inside the classroom.

This study investigated whether the activities and assessment in an extensive reading (ER) program could be used to develop students' critical thinking skills, such as in making inferences, reasoning, and explaining. It aimed to determine to what extent the students' critical thinking ability improved through such ER program. Students' perspectives about the program were also investigated. This study involved students who were enrolled in English Education department, which implies that they were training to become prospective English teachers. Teachers certainly need to have good critical 
thinking skills as well as reading skills. Therefore, the development of the skills should be taken into consideration when developing a course for these prospective teachers.

\section{METHOD}

The aim of this study was to assess whether activities and assessment in an ER program could be used to improve the students' critical thinking ability and to find out the students' perspectives of the program. This study employs mixed-method design as there were two types of the data collected. It recorded pre- and post- critical thinking test scores. It also surveyed the students' thoughts after the program.

The Critical Thinking Assessment Practice Quiz (see Appendix 1) from Learning Express LLC (Starkey, 2010) was used to assess the students' critical thinking ability. It consists of 30 multiple-choice questions in English which are designed to evaluate the test takers' ability, especially in reasoning. The test was given at the beginning and at the end of the program to see whether there was any improvement in the students' critical thinking skills.

The research was conducted in an English Education Department (EED) at a university in West Java. The students at EED were at an advanced level of English proficiency and they had a specific objective: to become future English teachers. Forty research participants ( 7 males, 33 females), from 18 to 21 years age range, from three classes in their fourth semester of undergraduate study were involved. These participants were enrolled in an ER course; they made up 49 per cent of a total of 82 students taking the course at that time. They were the ones who took the pre- and post-reading tests.

The extensive reading in the EED was integrated with other skills to get the maximum benefit of ER. All language skills were used in the ER activities. Within those skills, critical thinking plays an important part of their learning. Each type of class material had a different type of assessment. In their fourth semester (4.5 months at the end of their second year), they were assigned to read 28 different materials consisting of:

a. ten novels in English each with a minimum of 200 pages,

b. ten articles in English from journals or proceedings, each being 5 to 30 pages,

c. eight English textbooks that could be in the form of reference works, instructions, or workbooks which have to include two biographies. 
The ER subject itself was worth three credit points, which meant per-week they had 150 minutes in class (120 minutes presentation and 30 minutes silent reading), 150 minutes independent learning out of class, and 150 minutes structured assignments such as writing a review of a novel and a summary of a book and an article, and making YouTube presentations. Those assignments were assessed using a rubric to assess the students' critical thinking skills.

In the ER subject, the students could choose any type or genre from the listed novels in the EED Reading Corner library. One title could be read by a maximum of two students, who had to be from different classes in order to control their reading and to minimize the chances of cheating. After reading, they had to answer the questions on the Book Response Form within a maximum of two pages of A4 paper (see Appendix 3).

To get maximum points, the students had to exercise some critical thinking skills to support their answers, such as, by giving evidence, providing reasons, analyzing the story, and correlating it with their own thoughts or opinion (Facione, 2015; Facione, Sanchez, Facione, \& Gainen, 1995; Wilhelm, 2004). Critical thinking skills were also implemented in the oral presentation in class. After the presenter finished retelling the story, the audience would ask questions and explain why their questions were important to address. Meanwhile, for book reading, the requirement was in the form of writing a summary based on book types. The types of books and the form of summary were explained in class. Examples given included using SQ3R methods. SQ3R has five steps: survey, question, read, recite, and review (Thomas \& Robinson, 1972) for reference type textbooks (books that have chapters and sub-chapters). The students were also required to write a simple summary for each article. In the summary, they were encouraged to express opinions and provided reflection (Facione, 1990) as part of their critical thinking skill practices.

\section{FINDINGS AND DISCUSSION}

\section{Findings}

The critical thinking test was given before the program started and after the program ended. There were thirty questions in each test with the alpha level of .05 used for all statistical calculation in this study with a $95 \%$ degree of trustworthiness. It means that the result of this statistic calculation would have $5 \%$ of error probability and has $95 \%$ level of certainty of being accepted. 
In order to calculate the difference between the pre-test and post-test, finding the means was done first. The result can be seen in Table 1.

Table 1. Paired Samples Statistics

\begin{tabular}{cccccc}
\hline & & Mean & N & Std. Deviation & Std. Error Mean \\
\hline \multirow{2}{*}{ Pair 1 } & Pre-CT & 8.28 & 40 & 1.853 & .293 \\
\cline { 2 - 6 } & Post-CT & 16.75 & 40 & 3.144 & .497 \\
\hline
\end{tabular}

$\operatorname{Max}=30$

The students' mean score in the post-test, as shown in Table 1, was 16.75, more than two-folds of the pre-test mean of 8.28. It means there was an improvement in the students' critical thinking skill after the ER program. However, to find out whether the improvement was significant or not, another calculation should be conducted. The result could be seen in Table 2 .

Table 2. Paired Samples Test

\begin{tabular}{|c|c|c|c|c|c|c|c|c|c|}
\hline & & \multicolumn{5}{|c|}{ Paired Differences } & \multirow{3}{*}{$\mathbf{t}$} & \multirow{3}{*}{ df } & \multirow{3}{*}{$\begin{array}{l}\text { Sig. } \\
(2- \\
\text { tailed) }\end{array}$} \\
\hline & & \multirow[t]{2}{*}{ Mean } & \multirow[t]{2}{*}{$\begin{array}{l}\text { Std. } \\
\text { Deviati } \\
\text { on }\end{array}$} & \multirow[t]{2}{*}{$\begin{array}{l}\text { Std. } \\
\text { Error } \\
\text { Mean }\end{array}$} & \multicolumn{2}{|c|}{$\begin{array}{l}\text { 95\% Confidence } \\
\text { Interval of the } \\
\text { Difference }\end{array}$} & & & \\
\hline & & & & & Lower & Upper & & & \\
\hline $\begin{array}{c}\text { Pair } \\
1\end{array}$ & $\begin{array}{c}\text { Post-CT } \\
- \\
\text { Pre-CT }\end{array}$ & 8.475 & 2.572 & .407 & 7.652 & 9.298 & $\begin{array}{c}20.8 \\
41\end{array}$ & 39 & .000 \\
\hline
\end{tabular}

Based on Table 2, the sig. value (2-tailed) was smaller than alpha value $(0.05)$, and so it is argued that the scores in the pre-test were significantly different from those on the post-test, meaning that the implementation of the ER program which integrated critical thinking skills in the activities and assessment affected the students' critical thinking skill scores. It was supported by the result of the paired sample $t$-test where value of $t=20.841$ was higher than that in the set $t$ - value of 2.021 , allowing us to reject the null hypothesis. It means that the pre-test scores were significantly different from the post-test scores and that the ER program affected the students' critical thinking skills. To find out the level of the effect, Hake's (1999) n-gain criteria test was applied. The result is in Table 3 . 
218 TEFLIN Journal, Volume 30, Number 2, July 2019

Table 3. One-Sample Statistics

\begin{tabular}{ccccc}
\hline & $\mathbf{N}$ & Mean & Std. Deviation & Std. Error Mean \\
\hline N-gain & 40 & .09242 & .028092 & .004442 \\
\hline
\end{tabular}

However, based on the n-gain criteria proposed by Hake (1999), the mean value was 0.09242 , which means it was in the low criteria $(\mathrm{g}<0.3)$. The next test was conducted to see the meaningfulness of the n-gain (Table 4).

Table 4. One-Sample Test

\begin{tabular}{|c|c|c|c|c|c|c|}
\hline & \multicolumn{6}{|c|}{ Test Value $=0$} \\
\hline & \multirow[t]{2}{*}{$t$} & \multirow[t]{2}{*}{ df } & \multirow{2}{*}{$\begin{array}{l}\text { Sig. (2- } \\
\text { tailed) }\end{array}$} & \multirow{2}{*}{$\begin{array}{c}\text { Mean } \\
\text { Difference }\end{array}$} & \multicolumn{2}{|c|}{$\begin{array}{l}95 \% \text { Confidence Interval } \\
\text { of the Difference }\end{array}$} \\
\hline & & & & & Lower & Upper \\
\hline $\mathrm{N}$-gain & 20.808 & 39 & .000 & .092423 & .08344 & .10141 \\
\hline
\end{tabular}

Based on the results of the one sample test in Table 4, we see $t=20.808 p$ $<.001$, which shows that the students' $\mathrm{n}$-gain was meaningful even though it has low criteria. This means that the provision of the ER program has an effect on the critical thinking score improvement, even though it has only recently reached a low level on the effectiveness criteria $(0.09242<0.3)$. However, the result of the Cohen effect size was 0.853 , which means that the ER program had a high influence on increasing the average critical thinking test score because it was within $0.8<\mathrm{d}<2.0$ (big effect).

In terms of the students' perspectives of the program, the following were some of the students' impressions about their critical thinking ability after the ER program quoted verbatim from their reflections. Overall, the students felt that they had improved their critical thinking skills, such as, in evaluating what they read, in reasoning, and in connecting what they read to their real life, as they did the activities in the ER program. 
Husna, Developing Students' Critical Thinking through ER Program 219

\begin{abstract}
Student 1
After participating in the ER, I applied critical thinking to other courses more often because now I understand how critical thinking works. I also felt that my English skills, especially vocabulary, have improved significantly because I always read novels and met many new vocabularies for speaking skills. Because I always present novels, and textbooks and ask questions to friends who present theirs, so I become brave enough to talk.
\end{abstract}

\title{
Student 2
}

For critical thinking skills, Alhamdulillah, I feel the changes. Right now, I am getting used to not receiving information raw from a source, and start thinking more deeply. I feel that Extensive Reading is needed in learning English because this course provides many benefits for students.

\section{Student 3}

What I have got after I finished this ER course, it was a spectacular experience I have ever felt. In the beginning, it was 'Wow!' and exciting because I assumed it as a challenge to read 28 books written in English in one semester. It is appropriate for students who study the English, especially for my friends and I who will become English teachers. The things that were improved after the course are my vocabulary, critical thinking and speed-reading skill. The activity I like the most is taking moral value from those novels that I have read. It was pleasing because it is worthy to be applied in my daily life. I think this course is great and really needed. Every 4th-semester student have to have this course.

\section{Discussion}

From the findings, it could be seen that there was a significant improvement in the subjects' ability in using critical thinking after the ER. The average score on the post-test was twice more than the pre-test average score. These results are in line with the previous research which found that the subjects had improved their thinking management through ER (Husna, 2017). It was also found that by including some critical thinking skill activities as a part of their required assignments (reviews, summary, presentations), the students became used to thinking before they acted; they learned to be more objective and sensitive; they also developed their curiosity and ability to elaborate their ideas. Based on the results from the pre-test to the post-test, it was shown that the ER, the assessment and the activities had improved the students' ability in applying critical thinking skills. 
Most of the students ( 72 of the full population of 83 students taking ER courses) gave more or less the same positive impression. It seems that the requirement or the criteria in the assessment has empowered the students to practice the critical thinking skills of interpretation, analysis, evaluation, inference, explanation, and self-regulation as the core of critical thinking (Facione, 2015). In the assessment, the subjects needed to give the reason for their chosen answer by relating it to their opinion and the story. Another example of the use of critical thinking skills was they had to argue why and how the plot should be changed and why they wanted it that way. By continuing to practice those activities, they learned to elaborate their opinions and improved their imagination, as well as being able to defend their choices. Those activities required them to show their active cognitive skills in interpreting, analyzing, and explaining. The regular practice of those activities helped them to learn how to solve problems (Wong, 2016) because they would keep questioning their thoughts while analyzing.

Even though the correlation showed moderate closeness, it was statistically significant. Therefore, it can be stated that those assessments in ER are related closely to the improvement of the students' critical thinking skills, as shown in the results of the critical thinking test and it is essential that it be applied in classes because it could significantly improve the students' critical thinking ability. However, the need to develop the students' critical thinking skills would require systematic planning (Husna, 2017). It means that to implement the skills, a careful planning of teaching methods and assessment is imperative.

The oral activities in this program as part of the assessment also required the students to practice their critical thinking skills. These data show, that in order to practice higher order thinking, questions should be asked by the audience after an oral report in English. Such is in order to benefit not only the speaker but also the listeners. The listeners had to listen carefully to their peers' presentation to analyze the plot before they created questions. It means, they must not only understand the story, but they also needed to question the part of the story that they consider odd or make them curious. Analyzing process is an essential step in critical thinking practice (Facione, 2015; Jimenez et al., 2010). During this study, most questions given by the students to their peers asked the reasons for actions or events. Sometimes arguments would appear if the audience had known the story already and there was disagreement. The ability to discuss or to debate something relies on knowing the story or news item, and 
by gathering some other information to see things from a different perspective (Jimenez et al., 2010). This study shows that these types of activities can develop the students' mental alertness and intellectual curiosity (Facione et al., 1995; Eftekhary \& Kalayeh, 2014), and have a high influence on the students' critical thinking ability.

The tasks that required the students to add reasons for almost all answers and questions gave them chances to practice their cognitive skills to think before they act, see problems from different perspectives, and thoughtfully present an argument (Chaffee, 2014). Practicing these skills is an essential life skill for these students which will help them to avoid making poor decisions, and can improve their quality of life and opportunities (Jimenez et al., 2010).

Students doing critical thinking activities should receive some instructions on how to do it correctly, but this cannot be done in one session. To practice these skills, we do not need to wait until the students reach the university level, as it can be started earlier in their English learning (Eftekhary \& Kalayeh, 2014). The system in schools could be designed to help the students develop some of the aspects of critical thinking such as intellectual integrity, openmindedness, mental alertness, systematic diligence, confidence in the use of reason (Eftekhary \& Kalayeh, 2014), and intellectual curiosity (Facione et al., 1995).

\section{CONCLUSIONS}

Teachers need to facilitate the development of the students' critical thinking skills by providing relevant activities, which can be embedded within any subject, with some creativity from the teachers. To be able to have a wider perspective and empower their cognitive skills, students should be motivated to become lifelong readers and relate their reading to their real world. Learning a lot of information through extensive reading and discussing it with others will foster their intellectual growth. They will also be more open-minded persons who can accept others' thoughts without losing the ability to make fair judgments. This study has shown the potential to integrate critical thinking in an ER program through the activities and assessment. The students involved also shared positive perceptions of the program. Even though it might be difficult to start, and the students were not familiar with the challenge of the reading load and assessment in the extensive reading program implemented, with appropriate support from the teacher, the ER program turned out to be an 
exciting challenge for all students and one from which they developed their critical thinking skills.

\section{REFERENCES}

Bell, T. (2001). Extensive reading: Speed and comprehension. The Reading Matrix 1(1). Retrieved from http://www.readingmatrix.com/articles/bell/

Camarata, S. (2017). The emerging crisis in critical thinking. Retrieved from https://www.psychologytoday.com/us/blog/the-intuitiveparent/201703/the-emerging-crisis-in-critical-thinking.

Chaffee, J. (2014). Thinking critically. Stamford: Cengage Learning.

Eftekhary, A. A., \& Kalayeh, K. B. (2014). The relationship between critical thinking and extensive reading on Iranian intermediate EFL learners. Journal of Novel Applied Sciences, 3(6), 623-628.

Facione, P. (2015). Critical thinking: What it is and why it counts. Retrieved from https://www.insightassessment.com/About-Us/Measured-Reasons/ pdf-file/Critical-Thinking-What-It-Is-and-Why-It-Counts-PDF

Facione, P. (1990). Critical thinking: A statement of expert consensus for purposes of educational assessment and instruction (The Delphi Report). Newark: American Philosophical Association.

Facione, P., Sanchez C. A., Facione, N. C., \& Gainen, J. (1995). The disposition toward critical thinking. The Journal of General Education, 44(1), 1-25.

Facione, P., Facione, N. C., \& Giancarlo C. A. F. (1997). Professional judgment and the disposition toward critical thinking. Millbrae, CA: The California Academic Press.

Halpern, D. F. (1999). Teaching for critical thinking: Helping college students develop the skills and dispositions of a critical thinker. New Directions for Teaching and Learning, 80, 69-74.

Husna, N. (2017). Practicing critical thinking through extensive reading activities. In A. G Abdullah, I. Hamidah, S. Aisyah, A. A. Danuwijaya, G. Yuliani, \& H. S. Munawaroh (Eds.), Ideas for 21st century education (pp. 3-8). London: CRC/Belkema, Taylor \& Francis Group.

Jimenez, G., Haydee, L., Rosales, O., \& Soraya, E. L. (2010). Extensive reading: A meaningful tool to develop critical thinking in ESL students at a university level. Foreign Language Department, School of Arts and Science, University of El Salvador. Retrieved from 
Husna, Developing Students' Critical Thinking through ER Program 223

https://pdfs.semanticscholar.org/9247/bb715ace7304359ece7fbaaab54b8f 45ab69.pdf

Paul, R., Elder, L., \& Bartell, T. (2007). Study of 38 public universities and 28 private universities to determine faculty emphasis on critical thinking in instruction. Commission on Teacher Credentialing, California.

Pikkert, J. J. J., \& Foster, L. (1996). Critical thinking skills among third year Indonesian English students. RELC Journal, 27(2), 56-64.

Reed, J. H. (1998). Effect of a model for critical thinking on student achievement in primary source document analysis and interpretation, argumentative reasoning, critical thinking dispositions, and history content in a community college history course. Florida: University of South Florida.

Starkey, L. B. (2010). Critical thinking skills success in 20 minutes a day. New York: Learning Express.

Tabačková, Z. (2015). Outside the classroom thinking inside the classroom walls: Enhancing students' critical thinking through reading literary texts. Procedia-Social and Behavioral Sciences, 18, 726-731.

Thomas, E. L., \& Robinson, H. A. (1972). Improving reading in every class: A sourcebook for teachers. Boston: Allyn \& Bacon.

Wilhelm, O. (2004). Measuring reasoning ability. In O. Wilhelm \& R. Engle (Eds.), Handbook of understanding and measuring intelligence (pp. 373392). Thousands Oaks, CA: Sage Publication.

Wong, B. L. (2016). Using critical-thinking strategies to develop academic reading skills among Saudi IEP students (Master's Thesis, Hamline University, Minnesota, USA). 


\section{APPENDICES}

\section{Appendix 1. A Sample of the Questions from the Critical Thinking Test}

\section{Critical Thinking Assessment Practice Quiz}

This practice test is designed to help you figure out how much you know about critical-thinking skills. You may find that you know more than you think you do, because you use these skills in day-to-day living. You may discover that many questions on the practice test are easy to answer, but there could be some you find more difficult. This will help you pinpoint any skills you need to work on.

The practice test has 30 multiple-choice questions. Take as much time as you need to finish the practice test, and then check your answers on the answer key at the end.

1. You conducted a successful job search, and now have three offers from which to choose. What can you do to most thoroughly investigate your potential employers? (Choose all that apply.)

a. check out their websites

b. watch the news to see if the companies are mentioned

c. research their financial situations

d. speak with people who work for them already

2. Which is NOT an example of a persuasion technique?

a. "If you care about the environment, and who doesn't, give generously to our Save the Mongoose Fund today!"

b. "I've been eating Wheat-O's cereal since I was a kid," says superathlete Mark Guyerman. "They give me energy to win ... and they'll do the same for you!"

c. Soft-Sole Sneakers for toddlers are available at Murphy's Discount Store.

d. "Send me to Washington as your senator if you want things done. I'll stop all the government waste!" 
3. Choose the best conclusion for an argument that begins, "The other members of Philip's swim team ..."

a. won their events, so Philip will win his event, too.

b. have been swimming for at least six years, so Philip has been swimming for six years, too.

c. prefer to swim in outdoor pools, so Philip prefers outdoor pools, too.

d. wear swim trunks with the school logo on them, so Philip wears them, too.

4. Marcy's American Lit teacher gives a quiz every Monday on the 50 pages of reading he assigns on Fridays. His quizzes are becoming harder as the semester progresses, and Marcy hasn't been doing very well on them. What can she do to troubleshoot the problem and hopefully get better grades on the quizzes?

a. plan to get to class early on Monday to skim the pages

b. look for a new outfit to wear on Monday so she'll be relaxed

c. set aside time on Sunday to read and review the new material

d. spend an hour on Saturday looking over what she missed on past quizzes

5. Which is NOT a sound argument?

a. Sabrina wanted to be a better figure skater, so she took extra lessons and practiced every day. Her skating improved so much that she entered a competition.

b. Yesterday, a black cat ran in front of me, and later, I lost my wallet. If I don't see that black cat today, I won't have any bad luck.

c. We had a storm last night with hurricane-strength winds, and many trees were downed. There was a citywide power outage.

d. On a clear day, I can see the top of Murphy Monument from my house. If it's clear tomorrow, I'll be able to see the monument.

6. You are trying to decide what kind of car to buy. You make a chart to compare a two- seater sports car, a two-door sedan, and a minivan in three categories. Which would NOT be a suitable category?
a. price
b. gas mileage
c. tire pressure 
d. storage capacity

7. Which scenario best represents a situation that has been decided by emotion alone?

a. Sue hates the winter, so even though she can't afford it, she takes a vacation to the Bahamas.

b. The school shuts down after a bomb threat.

c. Third-quarter earnings for Marie's company were much higher than predicted.

d. Alexis needs a new mixer, so she watches the newspaper ads and buys one when it goes on sale.

8. When would it be better to do research in the library rather than on the Internet?

a. You are writing a report on recent U. S. Supreme Court decisions.

b. You want to know the historical performance of a stock you are considering purchasing.

c. You need to compare credit card interest rates.

d. You want to find out more about the old trails through the forest in your town.

9. You read a story in the newspaper about salary negotiations with public transportation workers. The workers are threatening to go on strike tomorrow if their demands for higher wages and better benefits are not met. What can you infer from this news story?

a. Health insurance premiums are very expensive.

b. The cost of gas will make ticket prices increase in the next few weeks.

c. People who ride the bus should look for possible alternative transportation.

d. Employers never like to meet salary demands.

10. What is wrong with this argument? "You think we need a new regulation to control air pollution? I think we already have too many regulations. Politicians just love to pass new ones, and control us even more than they already do. It is suffocating. We definitely do not need any new regulations!"

a. The person speaking doesn't care about the environment. 
Husna, Developing Students' Critical Thinking through ER Program 227

b. The person speaking has changed the subject.

c. The person speaking is running for political office.

d. The person speaking does not understand pollution.

The complete test can be downloaded from:

https://online.columbiasouthern.edu/csu_content/courses/general_studies/lss/lss5100/1

4b/lessons/unitiii_criticalthinkingassessmentpracticequiz.pdf 


\section{Appendix 2. Example of the Students' Work}

I don't like the part when Rhita persuaded the queen to support her like the queen support Patricia. Although Rhita's expcriment succeeded in expanding the test gate to a usable size, but actually it warned her that whocver opened the gate in the first place was not a human. Because of this, the Jart could come to Gaia and started storing and digitizing all the data and life forms on Gaia and it was very dangerous situation. Only because of her curiosity to reveal the truth from the data left by Patricia, Rhita was about destroying (Gaia. This part for me was annoying because the character of Rhita that was described very kind before became a very careless charactcr. And her action was not only endangering herself but also the people.

It was quite hard to relate the story to my experience. This novel is mostly talking about science knowledge that I do not know. But I was thinking that if it is truc there is a gate which connecting the earth to other place/planet so may be the issues of an existing alien or other creature outside the earth could be proved someday. My thought toward this discourse is that there will be always hidden mystery and revealed mystery beyond the human life. I do believe that as human we never life alone (outside the religion context), but science will always give surprising discoverics to us by the time. The limited knowledge had by human would never give satisfying answers for our questions, but I believe in one thing; if the Almighty God doesn't show us something, we have to look for it or just leave it (based on our range and capacity)

For me, the stand out character of this novel is Stopmouth. He was strongly described as the main character by the author. I like him because he was a sincere and responsible man. I could see it when he always helped his brother, Wallbreaker, while they were hunting their rival species to survive and he also liked to help his friends in another hunting, although for one moment he almost got killed by the creatures which they were hunting and got paralyzed, but it made him not to surrender casily, he still helped his friends to hunt after he recovered himself. Besides that, he also showed his responsibility when he helped a strange beautiful woman who fell from the sky, Indrani, to escape from his brother who married her but treated her badly. He helped her to get back to her home land and protected her during the journey. I always like responsible men. 
I think it would be fun if I could be Indrani. She was a unique woman. She was different from the other women who lived in tribes. She had got dark mesmerized eyes, long grey hair, as if everything in her was beautiful and stunning. She was also innocent, it obviously looked when she learnt Stopmouth's tribe's language for the first time, and it had completely distracted Stopmouth to fall his heart for her. The author also described Indrani as a strong woman; she could fight as a man and could protect herself from the other harmful creatures. This made me felt that Indrani was lucky to win Stopmouth's heart with her original nature. A sincere and responsible man with a beautiful and innocent woman, that's a perfect match I think because the man could appear as the protector for the woman and it has been described in the entire story. How lucky Indrani was.

The interesting part of this novel was when Indrani made a confession about her feeling towards Stopmouth. It happened when he asked her whether there was never a moment when she might have, when she wanted to kiss him or not. And unpredictably she said that she had that such feeling many times even all the time. Just like when she talked to him, walked near him, even when he taught her new words of his tribe. For me, it's not easy to confess such this feeling freely, but Indrani did it without any anxiety. She even confessed it frankly. 
Appendix 3. Book Response Form

$$
\begin{array}{lr}
\text { (your name) } & \text { (student number) } \\
\text { Book Response Form } & \text { (class) }
\end{array}
$$

Book title:

Author:

Publisher:

Date published:

Number of pages:

Genre (write one): Book Code:

$\begin{array}{llll}\text { Mystery } & \text { Science fiction } & \text { Romance } & \text { Detective } \\ \text { Horror } & \text { Classical stories } & \text { Legend } & \text { Fairy tale } \\ \text { Epic } & \text { Adventure } & & \\ \text { other: } & & & \end{array}$

Basic requirements:

○ Larger issues dealt with or raised by the story

- The stand out characters that are identified

- What character you wish to be

○ Point of the story or behavior that is interesting

○ Part that you dislike most

○ How you would change the story

- Personal experiences or thoughts related to the book

- Moral issues or what you have learned or best quote

*The points of the requirement should be written in paragraph form 